\title{
THE ESTABLISHMENT OF THE EUROPEAN EXTERNAL ACTION SERVICE: THE EU IN SEARCH OF A STRONGER ROLE ON THE INTERNATIONAL STAGE
}

\begin{abstract}
Juan Santos Vara*
Summary: The Lisbon Treaty introduces major reforms to the external action of the European Union. The creation of the European External Action Service (EEAS) is one of the most important of these innovations, carried out with a view to improving the effectiveness, consistency and visibility of the Union on the international stage. The search for greater coherence between the different fields of external action and between these and other EU policies is in fact one of the most important underlying reasons for the institutional reforms introduced by the Lisbon Treaty. The objective of this paper is to analyse the main points of interest raised by the creation of the EEAS, in order to determine to what degree the organisation and functioning of the EEAS will contribute to improving the coherence and effectiveness of the external action of the European Union.
\end{abstract}

\section{Introduction}

The Lisbon Treaty introduces major reforms to the external action of the European Union. The creation of the European External Action Service (EEAS) is one of the most important of these innovations, carried out with a view to improving the effectiveness, consistency and visibility of the Union on the international stage. The search for greater coherence between the different fields of external action and between these and other EU policies is in fact one of the most important underlying reasons for the institutional reforms introduced by the Lisbon Treaty. ${ }^{1}$ While in Article 21.3 of the Treaty it is established that the High Representative of the Union for Foreign Affairs and Security Policy will assist the Council and the Commission in ensuring consistency between the different fields of its external action, and between these and its other policies, in Article 18.4 of the Treaty it is clearly specified that the High Representative 'shall ensure the consistency of the Union's external action'. One of the most

\footnotetext{
*Associate Professor of Public International Law and International Relations at the University of Salamanca (Spain).

1 See European Convention, 'Final Report of Working Group VII on External Action' CONV 459/02, 16 December 2002 and European Council 'Mandate to the IGC' SG 12218/07, 26 June 2007.
} 
prominent changes is without doubt the new role of the High Representative, which has been introduced to put an end to the dichotomy between the external projection of the EU within the context of the CFSP and other Community policies. The EEAS was created precisely to support the High Representative in the development of the many and complex duties entrusted to him/her by the Treaties, and, in particular, to ensure coherence in the EU's external action. This innovation is thus linked to the redefining of the role of the High Representative, who is also the Vice-President of the Commission, responsible for external relations, and President of the Foreign Affairs Council. As with the High Representative, the mission of the EEAS is to facilitate consensus in the decision-making process as regards foreign policy and to present the results of this consensus in the international context, chiefly through the delegations of the Union. ${ }^{2}$

The objective of this paper is to analyse the main points of interest raised by the creation of the EEAS, in order to determine to what degree the organisation and functioning of the EEAS will contribute to improving the coherence and effectiveness of the external action of the European Union. In this respect, special attention will be paid to the positions adopted by the institutions and Member States in the course of the negotiation process that preceded the adoption of the Council Decision of 26 July 2010 which established the organisation and functioning of the EEAS. ${ }^{3}$ The implementation of the EEAS, which took place in the final months of 2010, will also be taken into consideration. The final configuration of the EEAS is characterised by its great complexity. This is to a certain extent inevitable, since the creation of the EEAS responds to the same logic underlying the new role of the High Representative, that is, to combine in the same body those services of the Commission and Council which are involved in the external action, while also incorporating diplomats from the diplomatic services of Member States.

As regards the structure of the paper, the second section aims to examine the negotiation process between the institutions and Member States which preceded the decision to set up the EEAS, in which the European Parliament played a key role. The third section will be devoted to analysing the following issues: the legal status of the new European diplomatic service in the light of the responsibilities allotted to it, the departments and functions of the Commission and Council which have been transferred to the EEAS, the management of the Union's external co-operation programmes, the administration and staff of the EEAS, and

\footnotetext{
2 Richard G Whitman, 'Strengthening the EU's External Representation: The Role of the European External Action Service' (2010) European Parliament, Directorate-General for External Policies of the Union, Standard Briefing, 2.

Council Decision of 26 July 2010 establishing the organisation and functioning of the European External Action Service [2010] OJ L 201/30.
} 
the integration of EU delegations into the EEAS. Finally, in the last section a number of issues will be examined that will help to determine whether the EEAS will help to strengthen the external action of the EU.

\section{The negotiation process before the adoption of the Decision to set up the EEAS}

The provisions included in the Lisbon Treaty as regards the composition and functioning of the EEAS are relatively limited. Article 27.3 of the Treaty on the European Union limits itself to establishing that the EEAS is to comprise officials from relevant departments of the General Secretariat of the Council and Commission, as well as staff seconded from the national diplomatic services of Member States. It was agreed to postpone to a later date the task of detailed regulation of the organisation and functioning of the EEAS by a decision of the Council, adopted on the basis of a proposal by the High Representative after consulting the European Parliament and obtaining the consent of the Commission. The work involved in the creation of the EEAS had begun, in fact, a great deal earlier, within the framework of the Constitutional Treaty. ${ }^{4}$ Preparatory work began after the signing of the European Constitution in October 2004, though this was put on hold by the negative results of the referenda which took place in France and the Netherlands in $2004 .{ }^{5}$ The signing of the Lisbon Treaty led to the restarting of these preparatory activities in order that the EEAS would be in a position to begin operating as soon as the Treaty was approved. With a view to this, a final Declaration established that the preparatory work for the setting-up of the EEAS should begin as soon as the Lisbon Treaty was signed, without any need to wait for its ratification or application. ${ }^{6}$ The difficulties experienced in the ratification process of the Lisbon Treaty in the wake of the negative result of the Irish referendum in 2008 led to another slowing-down in the preparations for the creation of the External Action Service.

On 21 June 2010, the Spanish Presidency of the Union, the High Representative, the Commission and the representatives of the Europe-

\footnotetext{
4 On the preparatory work of the EEAS, see Simon Duke, The European External Action Service in the Making?'(2004) 2 (2) CFSP Forum; Laura Rayner, The EU Foreign Ministry and Union Embassies (The Foreign Policy Centre, London 2005); Clara Portela, 'El Servicio de Acción Exterior Europeo: Implicaciones para la Reforma del Servicio Diplomático Español' (2009) <http://www.falternativas.org/opex/documentos-opex/documentos-de-trabajo/elservicio-de-accion-exterior-europeo-implicaciones-para-la-reforma-del-servicio-diplomatico-espanol> accessed 20 March 2011.

5 See Joint Progress Report by the High Representative and the Commission on the European External Action Service, 9 June 2005 (CAB 24 RELEX 304), 9956/05; European Parliament Resolution on the institutional aspects of the European External Action, 14 May 2005 (OJ C 117E/233).

6 Declaration on Article 27 of the Treaty on European Union.
} 
an Parliament reached a political agreement as regards the organisation and functioning of the European External Action Service. This agreement made it possible for the European Parliament to grant its approval to the proposal of the High Representative a few days later, and for the Council to take on 26 July 2010 the decision establishing the organisation and functioning of the EEAS. ${ }^{7}$ This brought an end to the intensive negotiation process which had been going on between the institutions since 25 March 2010, when the High Representative presented a formal proposal regarding the EEAS. It is no surprise that negotiations between the various interested parties had been particularly complicated during this period. The new service involves the unification of the departments and functions of the Commission and Council which deal with the external action of the Union, but without altering the powers and functions entrusted to the institutions by the Treaties.

The work of the High Representative was facilitated by the Report of the Swedish Presidency on the European External Action Service, approved by the European Council on 29 and 30 October 2009, which reflects the consensus between Member States on fundamental aspects of the new Service. ${ }^{8}$ For this reason, it proved relatively easy to reach political agreement between Member States as regards the content of the proposal presented by the High Representative at the meeting of the Foreign Affairs Council on 26 April 2010. ${ }^{9}$ The proposal of the High Representative was nonetheless immediately rejected by the European Parliament, which was particularly unhappy about the lack of political control and the creation of a new service which is autonomous from the Commission. Even though the European Parliament did not manage to ensure the EEAS was converted into a Community body as such, the Parliament was certainly not the loser in the negotiation process that preceded the creation of the new body. In fact, in the period between the Parliament's rejection of Ms Ashton's proposal and the political agreement reached on 21 June 2010, the Parliament obtained significant concessions which strengthen both the role of the Commission in a number of important areas of the EEAS and the political control exercised by the European Parliament in relation to the High Representative.

Despite the fact that Article 27.3 of the Treaty merely requires consultation with the Parliament on the part of the Council as regards adopting decisions regarding the organisation and functioning of the EEAS,

\footnotetext{
$7 \quad$ European Parliament legislative resolution of 8 July 2010 on the proposal for a Council decision establishing the organisation and functioning of the European External Action Service (08029/2010 - C7-0090/2010 - 2010/0816(NLE)).

8 Presidency Report to the European Council on the European External Action Service, 23 October 2009, POLGEN 163.

9 EUROPE Documents no 2533, 30 April 2010.
} 
the Parliament was able to make full use of the opportunity provided by the fact that changes needed to be introduced to the Financial Regulation and to the Staff Regulations of Officials of the EU. In addition, modifications to the 2010 Budget for the setting-up of the European External Action Service had to be adopted by ordinary legislative procedure. ${ }^{10}$ In this way, the Parliament was able to ensure that the majority of its demands were included in the legal framework which regulates the functioning of the EEAS.

As well as gaining overall control over the management of the budget of the Service, the European Parliament obtained firm agreement on the part of the High Representative to seek the views of the European Parliament on the main aspects of, and basic choices involved in, the Common Foreign and Security Policy (CFSP), even prior to the adoption of mandates and strategies or the setting-up of new crisis management missions within the framework of the Common Security and Defence Policy (CSDP). ${ }^{11}$ This important concession on the part of the High Representative, which goes beyond what is required by Article 36 of the Treaty, provides a satisfactory response to the Parliament's traditional demand for a more active role in the formulation of the CFSP, which unquestionably reinforces the Parliament's political control over the more intergovernmental areas of the external action. Nevertheless, it will not always prove easy to achieve satisfactory consensus between the need to provide a rapid response to questions of great international importance and the maintenance of the confidentiality of the discussions, on the one hand, and the exercise of democratic control, on the other. For this reason, the Declaration on Political Accountability of the High Representative indicates that the prior exchange of impressions in relation to the CFSP will take place in the appropriate format, corresponding to the sensitivity and confidentiality of the topics discussed'. ${ }^{12}$ During the negotiations surrounding the decision, the Parliament also tried to improve its access to CFSP and CSDP classified documents. The High Representative has accepted the establishment of a procedure through which he/she will be able to provide access to this type of document to MEPs when this access is 'necessary to exercise its institutional function', subject to petition by

\footnotetext{
10 See Regulation (EU, Euratom) No 1080/2010 of the European Parliament and of the Council of 24 November 2010 amending the Staff Regulations of Officials of the European Communities and the Conditions of Employment of Other Servants of those Communities, OJ L 311/1, 26 November 2010; Regulation (EU, Euratom) No 1081/2010 of the European Parliament and of the Council of 24 November 2010 amending Council Regulation (EC, Euratom) No 1605/2002 on the Financial Regulation applicable to the general budget of the European Communities, as regards the European External Action Service, OJ L 311/1, 26 November 2010. The Definitive adoption of amending budget No 6 of the European Union for the financial year 2010 took place on the 20 October 2010, OJ L 20/2, 22 January 2011.

11 Declaration by the High Representative on political accountability, 2010.

12 High Representative (n 11) 1 para 2.
} 
the Commission of External Affairs and, if relevant, the President of the European Parliament.

The High Representative has also accepted that the European Union Special Representatives and Heads of Delegations recently appointed for countries and organisations deemed by the Parliament as strategically important appear in person, at Parliament's request, to exchange impressions before taking up their posts. It is specified clearly in the Declaration of the High Representative on Political Accountability that these appearances do not imply the establishment of a system of hearings before appointment, as the Parliament had claimed. Differences of opinion between the Parliament and the High Representative in terms of the interpretation of this agreement have not, however, been long in arising. At the beginning of October 2010, the High Representative cancelled the appearance of the Austrian diplomat Hans Dietmar Schweisgut, who had recently been appointed Head of the Delegation of the European Union in Japan. The High Representative rejected the Parliament's demand to hold a public debate when the Head of a Delegation had not yet taken up his / her position. ${ }^{13}$

At the same time, the Parliament obtained a pledge on the part of the High Representative as regards his/her replacement should she be unable to participate in a plenary debate in the European Parliament. In such circumstances, the High Representative will decide on his/her replacement by a member of an EU institution, that is, either by a Commissioner, for issues falling exclusively or predominantly under the competencies of the Commission, or a Member of the Foreign Affairs Council, for issues falling exclusively or predominantly in the CFSP field. The European Parliament was very keen to avoid the replacement falling to a high official of the EEAS from whom it would be difficult to demand political accountability.

The Parliament also obtained a pledge on the part of the High Representative on the basic organisation of the central management of the EEAS, in which, in particular, specific guarantees were offered regarding the creation of a body for the promotion of human rights within the central management structure as well as in the delegations. ${ }^{14}$ Because of this, it is no surprise that it has been claimed that the consultation

13 EU Observer, 'Ashton Calls off EU Ambassador Hearings', 5 October 2010, available at <http://www.euobserver.com> accessed 25 March 2011, and European Voice: 'Annoyed Ashton Cancels Diplomat Hearings', 5 October 2010, available at <http://www.europeanvoice.com> accessed 25 March 2011.

14 See Statement given by the High Representative in the plenary of the European Parliament on the basic organisation of the EEAS central administration, Annex to Report on the proposal for a Council decision establishing the organization and functioning of the European External Action Service, 6 July 2010, A7-0228/2010. 
process has been transformed into a 'procedure of de facto co-decision', since not only questions relating to the budget and personnel must be negotiated with Parliament, but also the organisation and functioning of the EEAS. ${ }^{15}$ To sum up, the European Parliament has taken full advantage of the opportunity to leave its mark on the set-up of the new Service. Nevertheless, the commendable desire on the part of the Parliament to introduce the maximum possible guarantees for political control over the High Representative and the EEAS has come into conflict with another aim that the Parliament has claimed for a very long time, namely the strengthening of the external action of the Union, of which the new agency constitutes a fundamental element. In October 2010, the Parliament was on the verge of blocking the funds required for the setting-up of the EEAS in December 2010, because it demanded specific guarantees regarding priorities in terms of recruitment of staff. ${ }^{16}$

\section{A new autonomous body of the European Union}

\subsection{The legal status and tasks of the EEAS}

During the decision-making process for the Council Decision of 26 July 2010 establishing the organisation and functioning of the EEAS, much discussion was devoted to the legal status of the EEAS. The Member States in principle opted for the creation of a kind of sui generis service, independent of the Commission and of the General Secretariat of the Council, which reflects the specific functions that it is to perform in the EU. ${ }^{17}$ The European Parliament, on the other hand, as has been pointed out in the previous section, defended the idea that the EEAS should be integrated into the administrative structure of the Commission in order to guarantee transparency and democratic control over its activities. ${ }^{18}$ Finally, the EEAS was set up in the form of a 'functionally autonomous body of the European Union, separate from the General Secretariat of the Council and from the Commission, with the legal capacity necessary to perform its tasks and attain its objectives'. ${ }^{19}$ In accordance with this, the

\footnotetext{
15 Ramón Jáuregui Atondo 'El Parlamento Europeo: Un Actor Decisivo en las Negociaciones sobre la Creación del Servicio Europeo de Acción Exterior' (2010) Real Instituto Elcano, ARI $147 / 2010$.

16 European Voice: 'MEP's Withhold Cash for New Diplomatic Posts', 5 October 2010, available at <http://www.europeanvoice.com> accessed 25 February 2011.

17 See High Representative and Commission (n 5) para 6; Presidency Report (n 8).

18 See press release, 'The Conference of Presidents on the External Action Service' 10 June 2010; Institutional aspects of creating a European service for external action, Report: BROK A7-0041/2009, 20 October 2009, approved by European Parliament Resolution of 22 October 2009 on the institutional aspects of setting up the European External Service (2009/2133(INI)).

19 Council (n 3) art 1.
} 
EEAS will be neither an institution nor an agency of the EU, nor a service dependent on the Council or the Commission, but an autonomous body dependent on the authority of the High Representative, who will act in close collaboration with both the Commission and the Council. ${ }^{20}$ This decision regarding the body's legal status is the most valid option, given the dual links of the High Representative with the Commission and the Council. As regards the Financial Regulation, however, it is considered to be an institution.

It is difficult, nevertheless, to carry out any examination of the legal status of the new European External Service without taking into account the responsibilities accorded to it in the Decision of 26 July 2010. In order to achieve coherence in the external action as a whole, the EEAS has a mission to assist the High Representative in both the exercise of his/ her mandate to manage the CFSP and the CSDP, and in his/her role as President of the Foreign Affairs Council and Vice-President of the Commission, responsible for the Commission in the external action, without prejudice to the normal responsibilities of the General Secretariat of the Council or Commission services.

Likewise, it is established that the EEAS will support and work in cooperation with the diplomatic services of Member States, as well as with the General Secretariat of the Council and Commission services, and with other institutions and organs of the Union, in particular the European Parliament. ${ }^{21}$ Collaboration with the diplomatic services of Member States is essential to ensure adequate defence and representation of the interests of the Union on the international stage. With this in mind, in the Treaty of the EU it is established that a substantial part of the staff of the new Service should come from the diplomatic services of Member States. Clearly, the creation of this new Service does not involve the transfer of new responsibilities to the institutions of the Union on the part of Member States. ${ }^{22}$

Collaboration with the Commission is inextricably linked to the fact that certain external areas have not been transferred to the EEAS (trade, enlargement, humanitarian aid) and neither has the external dimension of other internal policies (trade, climate change, energy, enlargement, the area of freedom, security and justice, etc.) Eventual friction between the

20 See Bart Van Vooren 'A Legal-institutional Perspective on the European External Action Service' (2010) Centre for the Law of EU External Relations, Working Papers, available at <http://www.cleer.eu> accessed 31 January 2011.

${ }^{21}$ Article 3.3 of the Decision (Council (n 3)) states that the EEAS may enter into service-level arrangements with relevant services of the General Secretariat of the Council, the Commission, or other offices or interinstitutional bodies of the Union'.

22 Natividad Fernández Sola, 'El Servicio de Acción Exterior de la Unión Europea' (2008) Real Instituto Elcano, Documento de Trabajo No 46/2008. 
EEAS and the Commission would be particularly damaging to enhancing the role of the EU on the international scene. In this context, special attention is paid to co-operation between the EEAS and the Commission in the Decision. In Article 3, it is specified that the 'EEAS and the services of the Commission shall consult each other on all matters relating to the external action of the Union in the exercise of their respective functions, except on matters covered by the CSDP. ${ }^{23}$ Although the exclusion of the CSDP may be explained in the light of the specific nature of defence and security issues, this is incomprehensible given the importance that is invested in the Treaty and in the very decision to create the EEAS with a view to guaranteeing the coherence of the external action as a whole. Fortunately, this obligation for co-operation extends to the other areas of the CFSP, so there remains a requirement for consultation and mutual support between the Commission and the EEAS as regards all initiatives related to the CFSP and other Community policies.

It is perhaps still too soon to determine whether the High Representative will, with the support of the new Service, be able to avoid interinstitutional conflicts like those of recent years regarding security and development. ${ }^{24}$ Nevertheless, it does not seem that the Lisbon Treaty has clarified precisely the boundaries between activities designed to attain CFSP objectives and those which are outside the remit of the CFSP, or that it has diminished the probability of new interinstitutional conflicts arising. ${ }^{25}$ The interconnection between the different fields of the external action is recognised by the Lisbon Treaty, which in Article 21 introduces for the first time a list of common objectives for all fields of the external action. In addition, while the old Article 47 of the EU Treaty offered priority to the measures adopted within the framework of the EC Treaty with a view to protecting the Community acquis as a whole against invasions on the part of intergovernmental pillars, Article 40 of the EU Treaty introduces a clause of mutual protection between the CFSP and the rest of

23 Catherine Ashton declared before the European Parliament that a Department assisting the HR in her task of ensuring consistency of the Union's external action will be established. Ashton said that 'this Department will inter alia provide input to and ensure follow up to the regular meetings of the HR with other members of the Commission. The Department will at service level assure the necessary interaction and coordination with competent Commission services concerning the external aspects of internal policies' (Statement given by the High Representative in the plenary of the European Parliament on the basic organisation of the EEAS central administration).

24 Case C-403/05 European Parliament $v$ Commission [2007] ECR I-9045 and C-91/05 Commission $v$ Council [2008] I-3651.

25 A good example is case C-130/10, pending before the Court, dealing with the legal basis for adopting targeted sanctions (Case C-130/10: Action brought on 11 March 2010 - European Parliament v Council of the European Union OJ C 134/26 (22 May 2010)). For a general analysis of this issue, see $\mathrm{J}$ Santos Vara, 'El control judicial de las sanciones contra Al-Qaeda y los talibanes en la Unión Europea: ¿un desafio a los poderes del Consejo de Seguridad?' (2009) 32 Revista de Derecho Comunitario Europeo 91. 
the external action of the EU. This disposition places the CFSP and other policies that form part of the external action on the same level. At the same time, the interdependence between the different areas of international relations implies that any intent to establish a separation between activities such as development aid and the CFSP is by its very nature artificial. In this context, the main challenge is to find the right balance regarding the boundaries between the CFSP and the other policies that form the sphere of the external action of the EU on the one hand, and the need to achieve coherence in the external action and representation of the Union on the other.

The EEAS is also entrusted with the specific function of assisting the President of the European Council, the President of the Commission, and the Commission itself in the exercise of their respective functions in the field of the external action. ${ }^{26}$ In light of the shake-up of the institutional system introduced by the Lisbon Treaty and of the quest for the much-desired objective of maintaining coherence between the different fields of the external action of the European Union, it seems logical that the function of supporting the President of the European Council and the President of the Commission should be allotted to the EEAS. ${ }^{27}$ In the Report of the Swedish Presidency, it is stated that

to ensure the consistency and better coordination of the Union's external action, the EEAS should also assist the President of the European Council and the President as well as the Members of the Commission in their respective functions in the area of external relations as well as closely cooperate with the Member States. ${ }^{28}$

Had the EEAS not been handed the task of assisting the President of the European Council, there was a risk that the latter would create its own bureaucratic body to support it in the field of foreign policy, thus endangering the desired unity in the international representation of the Union. ${ }^{29}$ Nevertheless, the exact way in which the External Action Service will respond to all of these potential demands for assistance is not yet known, ${ }^{30}$ and neither is it clear whether the intervention of the EEAS will entirely avoid discrepancies and competition between the High Representative and other Commissioners or between the President of the Commission and the President of the European Council.

\footnotetext{
26 Council (n 3) art 2.

27 See High Representative and Commission (n 5).

28 Presidency Report (n 8) para 3.

29 See Brian Cowe, 'The European External Action Service: Roadmap for Success' (2008) Chatham House Report, 19.

30 Simon Duke, 'The European External Action Service' (2010) European Institute of Public Administration, Policy Paper 2.
} 


\subsection{Composition of the EEAS}

As regards determining the departments and functions of the Council and the Commission that would be transferred to the External Action Service, there immediately arose two different views, an account of which has already been provided in the Joint Progress Report of 2005, where it was stated that a group of Member States would support a limited Service that would take charge of the fields covered by the CFSP and the CSDP, while other States considered that its mandate should be more extensive and should include fields such as the enlargement of the EU, relations with neighbouring states, and development. ${ }^{31}$ In accordance with the "minimalist' version, which emphasises the task of assisting the High Representative in the co-ordination of foreign policy, ${ }^{32}$ the new Service would be formed only by Directorate-General E, the Policy Unit of the Council, the Directorate-General for External Relations of the Commission and, in particular, Directorate A or the Crisis Platform. The creation of an External Action Service focused exclusively on the international representation of the EU in the fields of the CFSP and CSDP would have been against the very basis for the EEAS's existence, set up as it was precisely to tackle the problems of ineffectiveness and coherence between external relations and the CFSP, as well as to improve co-ordination between the external action of the Union and the foreign policies of the Member States. ${ }^{33}$

In accordance with the 'maximalist' model, all the DGs of the Commission that form part of the family of 'External Relations', that is External Relations, Development, Enlargement and Humanitarian Aid, would be transferred, with the sole exception of the Trade DG. ${ }^{34}$ In the Joint Progress Report of 2005, it was pointed out that in light of the functions attributed to the High Representative, and in particular the task of ensuring the coherence of the EU's external action as a whole, 'the EEAS must be able to provide evaluations and unified political reports not only to [the High Representative of the CFSP], but also to other Commissioners and to the President of the European Council'. ${ }^{35}$ For this reason, the EEAS should include geographic desks that cover all the countries

\footnotetext{
31 High Representative and Commission (n 5) para 8.

32 Simon Duke, 'Providing for European-Level Diplomacy after Lisbon: The Case of the European External Action Service' (2009) 4 The Hague Journal of Diplomacy 217.

33 For a similar opinion see Sophie Vanhoonacker and Natasja Reslow, 'The European External Action Service: Living Forwards by Understanding Backwards' (2010) 15 European Foreign Affairs Review 9.

34 In the Joint Progress Report, it is stated that the EEAS should comprise services currently dealing with CFSP (including CSDP), together with geographical desks covering all regions of the world and thematic desks dealing with issues such as human rights, counterterrorism, non-proliferation and relations with the UN' High Representative and Commission (n 5) para 8.

35 High Representative and Commission (n 5) Annex II, para 13.
} 
and regions of the world, without these being duplicated in the General Secretariat of the Council or in the Commission. Directorate General E and the Policy Unit, the General Staff and the EU Situation Centre would also be transferred from the Council. In the Report of the Presidency of 2009 , it was stated that in order for the High Representative to be in a position to comply with his/her responsibilities in the field of the CFSP, the Crisis Management and Planning Directorate (CMPD), the Civilian Planning and Conduct Capability (CPCC), and the Military Staff (EUMS) should all be integrated into the EEAS, 'while taking full account of the specificities of these structures and preserving their particular functions, procedures and staffing conditions'. ${ }^{36}$ There was at first no agreement between Member States on the possibility of integrating the Situation Centre into the EEAS. ${ }^{37}$ It should not be forgotten that the Member States remain unwilling to share assessments of their intelligence services, and that the Situation Centre also intervenes in the field of police and judicial co-operation in criminal matters, that is, it is involved with both external threats to the EU and security within the EU itself. ${ }^{38}$ In the end, the wise decision was taken to integrate the Situation Centre into the EEAS, given that its remaining outside the new Service would have considerably reduced the EU's ability to respond effectively to international crises. ${ }^{39}$

The 'minimalist' model might have had the perverse effect of separating the civil and military aspects of crisis management had military staff been excluded from the new Service. However, the 'maximalist' version did not seem acceptable for either the Commission or for the Member States. The transfer in their totality of several DGs might have weakened the Commission even more than it has already been weakened by the new institutional framework introduced by the Lisbon Treaty. Neither does it seem that the Member States would have accepted the creation of a Service in which a prominent weight was given to the departments originating in the Commission. The Member States have in fact shown great interest in making it quite clear that they continue to maintain control over their own foreign policy and that the CFSP continues to be governed by specific rules and procedures with a view to avoiding possible cross-contamination from Community mechanisms. In accordance with Final Declaration no 14, the regulations relating to the CFSP and in particular the new structures of the High Representative and External Action Service

\footnotetext{
36 Presidency (n 8) para 7.

37 High Representative and Commission (n 5) paras 8 and 12.

38 See Duke (n 32) 219.

39 In the Presidency Report to the European Council on the European External Action of 2009, it is recognised that 'the Situation Centre (SitCen) should be part of the EEAS, while putting in place the necessary arrangements to continue to provide other relevant services to the European Council, Council and the Commission' Presidency (n 8) para 7.
} 
will not affect the existing legal basis, responsibilities, and powers of each Member State in relation to the formulation and conduct of its foreign policy, its national diplomatic service, relations with third countries and participation in international organisations, including a Member State's membership of the Security Council of the United Nations. ${ }^{40}$

Finally, the composition of the new EEAS was established at an intermediate point between the two positions described. Besides the Policy Unit and the Directorate-General from the Council and Directorate-General for External Relations, highly significant parts of the DirectorateGeneral for Development, in particular those departments that deal with the planning and management of the Union's external co-operation programmes, along with the delegations of the Commission to third states and international organisations, came under its control. Because of this, the services that make up the DG Development are to be substantially reduced, maintaining only the fields of a thematic and horizontal nature. Within the context of the process of restructuring of the Commission, which has taken place in recent months as a result of the creation of the EEAS, the DGs Europe Aid and Development have been merged into the new DG Europe Aid-Development and Co-operation.

Development policy constitutes the sole field of the external action of the European Union which has been the subject of specific treatment in the Decision on the EEAS, a sign of the importance of the planning and implementation of development instruments in improving the coherence and effectiveness of the external action as a whole. While the management of the instruments of external action remains the responsibility of the Commission, a very important role is also played by the High Representative and the EEAS in the planning cycle. With regard to this, it may be mentioned that the High Representative and the EEAS are to work with the relevant members of the Commission and services throughout the whole cycle of programming, planning and implementation of the instruments referred to'. ${ }^{41}$ In particular, the EEAS shall have responsibility for preparing the decisions of the Commission regarding the strategic, multi-annual steps within the programming cycle, country and regional allocations, country and regional strategic papers, and national and regional indicative programmes. In any case, all proposals have to be prepared in accordance with the procedures of the Commission and then submitted to the Commission for adoption.

\footnotetext{
40 See Declarations 13 and 14 concerning the common foreign and security policy annexed to the Treaty of Lisbon. As has been pointed out, "the two declarations on CFSP in the Treaty of Lisbon indicate that there is still some uneasiness among the Member States about the implications of EU actions for existing national powers' Peter Van Elsuwege, 'EU External Action after the Collapse of the Pillar Structure: In Search of a New Balance between Delimitation and Consistency' (2010) 47 CMLRev 1001.

41 Council (n 3) art 9.3.
} 
There is, however, a very significant difference between the preparation of decisions within the framework of the Development Co-operation Instrument, the European Development Fund and the European Neighbourhood and Partnership Instrument on the one hand, and the remaining external assistance instruments on the other. As regards the former, it is specified that all proposals will be prepared jointly by the relevant services in the EEAS and the Commission, under the responsibility of the Commissioner responsible for Development Policy in the case of the Development Co-operation Instrument and the European Development Fund, and the Commissioner for Enlargement and European Neighbourhood Policy with regard to the European Neighbourhood and Partnership Instrument. ${ }^{42}$ Proposals are to be submitted jointly with the High Representative for adoption by the Commission. ${ }^{43}$ A Dastis has criticised the Commission's desire to intervene in all planning stages of these three instruments on the basis of its responsibilities for enlargement and development policies. ${ }^{44}$

In contrast, a more important role is entrusted to the Commissioner for Development as regards preparing the thematic programmes to be prepared by the appropriate service of the Commission and presented to the College of Commissioners after obtaining the agreement of the High Representative and the other relevant Commissioners. Nevertheless, this provision will not be applicable to some of the most important thematic programmes, such as the Instrument for Co-operation with Industrialised Countries and the Instrument for Nuclear Safety Co-operation. The EEAS will play a major part in the preparation of all the proposals of these Instruments. In this way, a differentiation has been established between long-term planning and annual or short-term planning. ${ }^{45}$

The High Representative and the EEAS will be jointly responsible for actions undertaken within the framework of the CFSP budget, part of the Instrument for Stability, the Instrument for Co-operation with Industrialised Countries, acts of communication and public diplomacy, and election observation missions. The Commission will be responsible for the financial implementation of these activities, under the authority of the High Representative in his/her capacity as Vice-President of the Commission.

\footnotetext{
42 See Mark Furness, The European External Action Service: A New Institutional Framework for EU Development Cooperation', Deutsches Institut für Entwicklungspolitik, Discussion Paper 15/2010.

43 Council (n 3) art 9.4.

44 Alfonso Dastis Quecedo, 'La Diplomacia Europea tras el Tratado de Lisboa' in José Manuel Sobrino Heredia (ed), Innovación y Conocimiento (Marcial Pons, Madrid 2010) 409.

45 Simon Duke and Steven Blockmans, The Lisbon Treaty Stipulations on Development Cooperation and the Council Decision of 25 March 2010 (Draft) Establishing the Organisation and Functioning of the European External Action Service' European Institute of Public Administration, working paper 2010/W/01, 9.
} 
In spite of the fact that the introduction of this differentiation between planning of development aid, on the one hand, and its management and implementation, on the other, is not free of controversy, it would have been difficult to achieve the much-desired objective of ensuring coherence between the different fields of the external action if development aid had been left outside the remit of the EEAS. ${ }^{46}$ The intervention of the EEAS in this important field of the external projection of the Union should not bring with it any change in the objectives and strategies of external co-operation programmes. In this sense, in the introduction to the Decision establishing the organisation and functioning of the EEAS, it is stated that it should respect the general objectives for external action established in Article 21 of the TEU and the objectives for development aid enumerated in Article 208 of the TFEU. Explicit references are also included to the European Consensus on Development ${ }^{47}$ and the European Consensus on Humanitarian Aid. ${ }^{48}$ The evaluation of the EEAS's contribution to improving the effectiveness of development aid depends to a large degree on its practical efforts to build up the coherence of development aid policy with other Union policies and co-ordination with the Member States, and of course its capacity to maintain a satisfactory level of co-ordination with the other actors of the Union involved in development aid, principally the Commissioner of Development. In my opinion, it is logical that a significant role be allotted to the EEAS in the planning phase, in which the strategic objectives of development aid are established with a specific country or region, in order to co-ordinate the actions of the Union in this field with the other policies that form part of the external action. Besides, if the management and planning of development aid had been left entirely outside the EEAS's remit, this would have led to an unnecessary duplication of geographical and thematic desks between the Commission DG entrusted with development policy and the structure of the EEAS. A duplication of this kind would go precisely against the logic that lies behind the creation of the EEAS, which is after all an instrument the aim of which is to improve the coherence and effectiveness of the EU's external action.

\footnotetext{
46 A group of NGOs has criticised the transfer of important responsibilities in the field of development aid to the EEAS. See M Van Reisen, 'Note on the Legality of Inclusion of Aspects of EU Development Cooperation and Humanitarian Assistance in the European External Action Service' EEPA Briefing Paper 2010; White and Case, 'Legal objection to the EEAS' involvement in EU development activities' 16 April 2010 (Memorandum), available at <http://www.cercle.lu/wp-content/uploads/imported/pdf/Legal_advice_on_EEAS_4.pdf> accessed 26 May 2011.

47 European Consensus on Development, OJ C 46 of 24 February 2006, 1.

48 Communication from the Commission to the European Parliament and the Council Towards a European Consensus on Humanitarian Aid COM (2007) 317 final.
} 


\subsection{Administration and staff}

In the Decision of 26 July 2010, it was established that the EEAS would be made up of a central administration and the official delegations of the Union to third countries and international organisations. An Executive Secretary-General, who will operate under the authority of the High Representative, will be responsible for the body's management, and the Executive Secretary-General will be assisted by two Deputy Secretaries-General. The Executive Secretary-General is responsible for ensuring effective co-ordination between all departments in the central administration, as well as with the Union Delegations.

The EEAS will be made up of a series of Directorates-General, of a non-specific number, which include several Directorates-General comprising geographic desks that cover all countries and regions of the world, as well as multilateral and thematic desks. It will also include a Directorate-General for administrative, staffing, budgetary, security and communication and information system issues, as well as the Crisis Management and Planning Directorate, the Civilian Planning and Conduct Capability, the European Union Military Staff and the European Union Situation Centre, placed under the direct authority and responsibility of the High Representative. ${ }^{49}$ It has been established that the specific character of these structures must be respected, as well as the particularities of their functions, recruitment and the status of staff. 50

Also part of the EEAS will be those individuals named by the High Representative to preside over the preparatory bodies of the Council, which are to be under the direction of the High Representative, including the President of the Political and Security Committee. While in the Decision to set up the EEAS it is not expressly stated that these individuals form part of the Service, unlike in the proposal presented on 25 March 2010, in the Appendix to the Decision of the European Council regarding the exercise of the Presidency of the Council and the presidency of the preparatory organs, it is established that if the designated individual does not form part of the EEAS, he/she will become a member, at least for the duration of his/her mandate. ${ }^{51}$

The recruitment of staff must be based on the merits of the candidates, and an appropriate geographical balance and fair proportion of men and women must be maintained. As regards determining how the division

\footnotetext{
49 Council (n 3) art 4.

50 The current structure of the EEAS is available at <http://eeas.europa.eu/background/ index_en.htm> accessed 26 May 2011.

51 Council Decision of 1 December 2009 laying down measures for the implementation of the European Council Decision on the exercise of the Presidency of the Council, and on the chairmanship of preparatory bodies of the Council [2009] OJ L 322/28.
} 
of staff among Member States is to take place, the Decision establishing the organisation of the EEAS only states that the new Service will comprise a meaningful presence of nationals from all the Member States. ${ }^{52}$ The establishment of a system based on national quotas is thus discounted, given the need to ensure a high level of professional skills and effectiveness on the part of the EEAS. In practice, a distinction is established between the initial moment of creation of the EEAS and the subsequent hiring of civil servants or diplomats to fill vacancies. While at the beginning the entire staff of the departments and functions listed in the annex to the Decision were transferred to the EEAS together, the subsequent selection process to fill vacancies will be based on a transparent procedure based on merit, 'with the objective of securing the services of staff of the highest standard of ability, efficiency and integrity'. ${ }^{53}$ Representatives of Member States, of the General Secretariat of the Council and of the Commission will be involved in the recruitment procedure for vacancies in the EEAS.

Guarantees of independence in the performance of the EEAS's functions are expressed in similar terms to those traditionally used for the civil servants of the Commission. The staff of the EEAS will act solely in the interests of the defence of the Union and will 'neither seek nor take instructions from any government, authority, organisation or person outside the EEAS or from any body or person other than the High Representative'. ${ }^{54}$ The strict fulfilment of this commitment is apparently somewhat problematic in the case of civil servants coming from the Council or diplomats of Member States, especially if they are to form part of the EEAS only for a limited period of time. The risk that national diplomats might act more in the interests of the States which they come from than in those of the European positions should not, however, be overestimated, given that, independently of their origins, all EEAS staff must exercise their functions bearing in mind only the common interests of the Union and acting under the authority of the High Representative.

The same treatment is to be accorded to the officials of the Union and staff coming from the diplomatic services of Member States who are appointed as temporary agents. All members of the EEAS will possess the same rights and obligations and will be treated equally as regards the assignment of duties to perform in all areas of activities and policies implemented by the EEAS. ${ }^{55}$ It is of fundamental importance that national diplomats joining the EEAS have the greatest possible training and experience for the new Service to be successful in the performance of its

\footnotetext{
Council (n 3) art 6.6.

Council (n 3) art 6.8.

Council (n 3) art 6.4.

55 Council (n 3) art 6.7.
} 
functions. ${ }^{56}$ Similarly, experience acquired in the EEAS will later be of benefit to national diplomatic services after diplomats return at the end of their period of service in the EEAS.

It is expected that the permanent officials of the Union should represent at least $60 \%$ of all EEAS staff at $\mathrm{AD}$ level, and that, in the longterm, staff from Member States should represent at least one third of all EEAS staff at this level. As well as this, the EEAS will also be endowed with a limited number of specialised seconded national experts, with a view to their providing specialised technical know-how. ${ }^{57}$ The creation of the EEAS will be a gradual process. On 1 January 2011, the date when the transfer of staff from the Commission and the Council actually took place, ${ }^{58} 1,643$ officials joined the EEAS, of which 118 were entirely new staff. The limited number of positions available still does not seem enough to fulfil the expectations of the 27 Member States. It is expected that when the body reaches its full operating capacity, it will have more than 5,000 agents. With regard to this, it has been pointed out that until a sufficient number of staff from the Member States are integrated into the organisation, it will be difficult for the delegations of the Union to perform the tasks of co-ordination and representation which the embassies of the State holding the rotating presidency of the Union have up to now been performing. ${ }^{59}$

The integration of civil servants from Member States and from the Commission and the Council at all levels of the EEAS will strengthen the non-partisan character of the new Service. ${ }^{60}$ The length of service of the civil servants of Member States will not be longer than eight years 'unless it is extended for a maximum period of two years in exceptional circumstances and in the interests of the service'. ${ }^{61}$

56 See Foreign Affairs Committee, Foreign Policy Aspects of the Lisbon Treaty (HC 2008, 120-I) paras 191-194.

57 Council (n 3) art 6.3. The High Representative shall adopt rules, equivalent to those laid down in Council Decision 2003/479/EC of 16 June 2003 concerning the rules applicable to national experts and military staff on secondment to the General Secretariat of the Council under which SNEs are put at the disposal of the EEAS in order to provide specialised expertise [2003] OJ L160/72.

58 Rapid, IP/10/1769, A new step in the setting-up of the EEAS: Transfer of staff on 1 January 2011, 21 December 2010, available at <http://europa.eu/rapid/pressReleasesAction.. o reference $=\mathrm{IP} / 10 / 1769 \&$ format $=\mathrm{HTML} \&$ aged $=0 \&$ language $=\mathrm{EN} \&$ guiLanguage $=\mathrm{en}>$ accessed 28 March 2011.

59 Dastis (n 44) 416.

60 It has been said that 'this mixture of backgrounds leads to the constructive integration of different strands of interest and argument, rather than a simple reproduction within the Service of institutional rivalries that have been traditional outside the Service' The Federal Trust for Education \& Research 'A More Coherent and Effective European Foreign Policy?' February 2009, 27.

61 Council (n 3) art 6.11. 
The Decision to create the EEAS stipulates that the members of staff of the EEAS are subject to a high degree of mobility, in particular between the central administration and the delegations. Because of this, all EEAS staff will in principle serve periodically in Union delegations. This rotation is essential for staff to acquire experience on the ground and also to avoid an excessive identification with the interests of the States in which they are posted. ${ }^{62}$ Likewise, it is stated that civil servants serving in the EEAS will have the right to apply for posts in their institution of origin under the same conditions as internal candidates. It is by no means impossible that in the long-term the existing links between the new Service and the staff's institutions of origin will be weakened, thus reinforcing the institutional autonomy of the EEAS. ${ }^{63}$

One of the topics that has been discussed during the process that has led to the creation of the EEAS is the opportunity to establish a European diplomatic school, which might provide common training to all the staff of the European diplomatic service and thus contribute to the promotion of a common diplomatic culture or a European identity in terms of foreign policy. While the Parliament has taken up the idea of the creation of a European diplomatic school with a great deal of enthusiasm, ${ }^{64}$ Member States have been much more cautious regarding this. ${ }^{65}$ This latter position is reflected in the text of the Decision on the creation of the EEAS, in which it is stated that 'steps will be taken in order to provide EEAS staff with adequate common training, building in particular on existing practices and structures at national and Union level', entrusting to the High Representative the adoption of appropriate measures to this effect within one year of the entry into force of the Decision. ${ }^{66}$ This is therefore one of the questions to which a more specific response will have to be provided once the EEAS has begun its operation and the main training needs of its staff have been identified.

\subsection{The Delegation of the European Union}

The improvement of the effectiveness and coherence of the EU's external action is closely linked to its international representation. The differentiation in the international representation of the EU to third states and international organisations depending on whether it is a matter of Community policy or CFSP policy has, on a number of occasions, translated into less coherent policy and reduced international visibility

62 Fernández (n 22) 15.

63 Maxime Lefebvre and Cristophe Hillion, The European External Action Service: Towards a Common Diplomacy?' [2010] European Policy Analysis 6.

64 European Parliament Resolution (n 18).

65 Presidency Report (n 8) para 24.

66 Council (n 3) art 6.12. 
for the EU. At the same time, the representation of EU foreign policy has been characterised by a lack of continuity caused by the rotating presidency of the Council, something which neither the establishment first of the troika and then the creation of the figure of the High Representative for Foreign Affairs and Security has managed to completely resolve. In these circumstances, it is understandable that the European Convention proposed transforming the delegations of the Commission into delegations of the Union. ${ }^{67}$ This proposal, which was initially included in Article III-328 of the Constitutional Treaty, is in Article 221 of TFEU, where it is stated that 'Union delegations in third countries and at international organizations shall represent the Union' and that they shall act in close cooperation with Member States' diplomatic and consular missions. This co-operation may be promoted in practice if Member States can reach agreement so that the heads of EU delegations preside over all meetings of accredited diplomatic representatives of Member States with third-party states and international organisations. It is by no means impossible that eventually the growing influence of the EEAS might be viewed as a threat by the diplomats of some Member States. Nevertheless, it is in the interests of Member States themselves to contribute to the establishment of the EEAS by sending qualified staff, sharing information and providing the body with all the co-operation necessary, both at central headquarters and on the ground. ${ }^{68}$ An increase in the effectiveness of foreign policy is, at least in theory, an objective which is shared by all Member States.

Given that EU delegations are under the authority of the High Representative, it is understandable that they have been integrated into the EEAS, even though this was not expressly stipulated in the Treaties. The transformation of Commission delegations into Union delegations will, as well as promoting a unitary perception of the EU in third-part nations, ${ }^{69}$ improve the international visibility of the EU by making its representation in its relations with third states and international organisations more transparent. ${ }^{70}$ The entering into force of the Lisbon Treaty has not led to the immediate conversion of Commission delegations into Union delegations, since their structures and composition needed first to be adapted in order for them to respond to the institutional changes introduced by the Lisbon Treaty, and particularly to the creation of the EEAS. ${ }^{71}$ Neverthe-

\footnotetext{
67 See Working Group VII (n 1) 6-7.

68 Cowe (n 29) 22.

69 Fernández (n 22) 9.

70 According to the Report of the Swedish Presidency, the delegations should assume as soon as possible the role and functions currently performed by the rotating Presidency in terms of local co-ordination and representation of the Union (Presidency Report (n 8)).

71 Alfonso Dastis Quecedo, 'The European External Action Service: Towards a Common Diplomacy?' in Francisco Aldecoa Luzárraga (ed), La Presidencia Española de la Unión Europea en 2010: Propuestas para una Agenda Ambiciosa (Marcial Pons, Madrid 2009) 65.
} 
less, before the Lisbon Treaty entered into force, there were two singular cases of joint representation of the Commission and the Council: the EU delegation to the African Union, opened officially in January 2008, and the EU representation in the ex-Yugoslav Republic of Macedonia, which began operating in February 2000.

The assumption of a greater prominence for the delegations of the Union as regards other international organisations is still faced with numerous legal and political obstacles. ${ }^{72}$ It is no surprise that in the Report of the Swedish Presidency the need to study on an individual basis the functioning conditions of Union delegations to international organisations had already been mentioned. ${ }^{73}$ The explicit attribution of international personality to the Union, along with the replacement of the rotating Presidency with the High Representative as regards the international representation of the EU in the CFSP area, certainly suggests that this would lead to an intensification of the Union's role in international organisations and forums, above all, in the United Nations. And yet nothing is further from the truth. The Union's proposal to obtain the status of advanced observer before the UN has recently been rejected by the General Assembly. In the last annual meeting of the General Assembly, the majority of developing countries expressed their wish to postpone voting on the resolution proposal presented by the Union, arguing that recognition of advanced observer status should also be extended to other regional organisations such as the African Union or CARICOM. ${ }^{74}$

In consequence, the Union continues to be considered as an ordinary observer at the United Nations, which does not exactly contribute to reinforcing the coherence, effectiveness and external visibility of the Union, as was intended by the changes introduced by the Lisbon Treaty. In the representation of the Union to the UN, the replacement of the rotating presidency by the High Representative, the President of the European Council, and by the EU delegation before the UN, is an operation that faces a number of obstacles, given that, unlike those who have represented the EU up to now, the Union is not a member of the United Nations and as such does not have the right to vote. ${ }^{75}$

Until this political and legal problem relating to the formal status of the Union is resolved, the only available option is to look for practical

\footnotetext{
72 This issue is directly linked to the participation of the European Union in international organisations. See J Santos Vara, La participación de la Unión Europea en las Organizaciones Internacionales (Colex, Madrid 2002).

73 Presidency Report (n 8) para 33.

74 Toby Vogel, 'UN General Assembly Postpones Vote on Special Status for the EU' (2010) European Voice, available at <http://www.europeanvoice.com/article/2010/09/un-postpones-vote-onspecial-status-for-eu/68858.aspx> accessed 13 March 2011.

75 See Katie Verlin Laatikainen, 'Multilateral Leadership at the UN after the Lisbon Treaty' (2010) 15 European Foreign Affairs Review 475.
} 
arrangements that allow the interests of the EU to be represented by one of the Member States in both the General Assembly and the Security Council. ${ }^{76}$ In this sense, Article 34 of the Treaty states that when all Member States are not represented in a particular international organisation, the States represented will keep the High Representative and other Member States informed of any matter of common interest. Specific mention of the Security Council is also made: 'when the Union has defined a position on a subject which is on the United Nations Security Council agenda, those Member States which sit on the Security Council shall request that the High Representative be invited to present the Union's position'. In other words, the situation remains just as it was before the Lisbon Treaty expressly introduced this clause. ${ }^{77}$

Though the Union delegations depend on the High Representative, the decision to open or close a delegation will be adopted by the High Representative in agreement with the Council and Commission. The delegations will include not only EEAS staff, but also staff from the Commission 'where appropriate for the implementation of the Union budget and Union policies other than those under the remit of the EEAS' ${ }^{78}$ As is the case with the diplomatic representations of individual States, it is obvious that Union delegations may include staff who do not form part of the EEAS but who are responsible for areas such as commerce, freedom, security and justice, transport, agriculture, etc. Nevertheless, the Head of Delegation shall have authority over all staff in the delegation, which does not prevent the Commission from giving instructions to its own staff, which will be executed under the responsibility of the Head of Delegation, with a view to ensuring the co-ordination of all actions of the Union.

Delegations will also be able to support Member States, should they request it, in their diplomatic relations and in their role of providing consular protection to citizens of the Union in third countries, in accordance with Article 35 of the Treaty. ${ }^{79}$ This is a stipulation that is directly related to the possibility that citizens of the Union, in the territory of a third country in which the Member State of which they are a national is not represented, be entitled to protection by the diplomatic or consular authorities of any Member State. In the Report of the Swedish Presidency, it is stated that ' $\mathrm{EU}$ delegations should play a supporting role as regards

\footnotetext{
76 For a similar opinion, see Cowe (n 29) 23.

77 On current practice regarding EU representation in the Security Council, see Nicoletta Pirozzi, 'The EU's Contribution to the Effectiveness of the UN Security Council: Representation, Coordination and Outreach', Instituto Affari Internazionali, Documenti IAI 10, July 2010 .

78 Council (n 3) art 5.

79 Council (n 3) art 5.10.
} 
diplomatic and consular protection of Union citizens in third countries' ${ }^{80}$ Putting this stipulation into practice will require, among other things, determining whether the delegations of the Union will limit themselves to providing consular assistance, or whether it is to be admitted that they will venture into the field of consular protection. The lack of precision in relation to the function of providing consular protection to citizens of the Union in third countries will be progressively cleared up. In any case, the assumption by Union delegations of the exercise of the diplomatic protection of European citizens will be dependent on the signing of an agreement with third-party states.

\section{Conclusions}

The EEAS brings with it the fusion of the main services and functions of the Council and the Commission as regards the formulation and management of external action. The composition of the EEAS is completed with the integration of diplomats from the diplomatic services of Member States. It is still perhaps too soon to determine if collaboration between staff from different departments of the Commission and Council, together with diplomats from Member States, will, under the auspices of the High Representative, help to develop an external action which is more coherent and effective, or whether it will act in accordance with the two different methods: the Community method on the part of staff coming from the Commission, and the intergovernmental one on the part of staff from the Member States and the Council, in particular those from the Political Unit and crisis management structures.

In my opinion, the new Service is capable of making a decisive contribution towards achieving a more coherent and effective EU on the international stage, but this will depend to a large degree on the will of the actors involved, particularly the Member States, and on the management abilities of Ms Ashton, who is responsible for the co-ordination of the different structures that comprise the EEAS. The new Service alone cannot make up for a lack of common interests in foreign policy or a lack of will to act in a spirit of honesty and mutual solidarity on the part of Member States when a common position has been adopted regarding a particular issue of international importance. The identification of common aims and interests in foreign policy is a key factor in the success or failure of the EEAS, though at the same time the existence of the body should make it easier for Member States to reach consensus on the key areas of external action. The discussions between Member States and the institutions which accompanied the establishment of the EEAS were not complemented by a debate on the strategic objectives the new institutio-

$80 \quad$ Presidency Report (n 8) para 32. 
nal structures for external action should aim to achieve, despite the fact that the major principles and objectives are stated in the Treaties and in a number of other documents, in particular the European Security Strategy.

It has been said that there is a risk of the new Service becoming in practice a kind of institution which is quite different from the Commission and the Council. Nevertheless, Article 27 of the Treaty clearly specifies that the EEAS's function is to support the High Representative in the execution of their mandate to direct the CFSP, and to act as President of the Foreign Affairs Council and Vice-President of the Commission responsible for external action, and that the High Representative is subject to the procedures that govern the functioning of the Commission and the Council. Besides, the creation of this new Service does not mean that the Commission is unable to intervene in future in the field of foreign affairs, since Article 17 of the Treaty states that the Commission will be responsible for the external representation of the Union, except in the case of the CFSP and other cases enumerated in the Treaties. Actually achieving the benefits that may come from the new organisational structure for external action requires the establishment of effective co-ordination between the activities of the new Service and the Commission. It is therefore essential to avoid, from the very beginning, any antagonism of a personal nature between the staff of the Commission and of the EEAS.

The establishment of the EEAS will naturally take place in a gradual manner, and its development will be subject to constant examination and review throughout the coming years in order to determine which changes to its functioning and organisation might be required to enable the new Service to develop an efficient and coherent foreign policy. As the European Parliament has pointed out, "the EEAS cannot be entirely defined or predetermined in advance, as it must establish itself progressively within a context of mutual trust and a growing heritage of shared know-how and skills'. ${ }^{81}$ For this reason, it is planned that at the end of 2011 the High Representative will present a report to the Parliament, the Council and the Commission on how the EEAS is functioning, and that in 2013 a full evaluation of the organisation and its functioning will be carried out, with a view to the presentation of possible proposals for a review of the Decision establishing the organisation and functioning the EEAS. ${ }^{82}$

It is certainly paradoxical, however, that the creation of an instrument the purpose of which is to improve the effectiveness and coherence of the EU's external action has generated such a battle among the institutions involved, when it comes to establishing the details of the organi-

81 European Parliament Resolution (n 18).

82 Council (n 3) art 13. 
sation and functioning of the new Service. The actions of both Member States and institutions have been guided more by the desire to obtain the largest possible influence in the new EEAS, or at very least to ensure that their existing powers as regards external action are affected as little as possible, than by the objective of creating a diplomatic service that is in accordance with the commercial, economic and political weight of the EU. Once the EEAS is actually operating, it is to be hoped that all actors involved in the development of the different policies that make up the external action will focus their efforts on supporting the EEAS in its task of facilitating consensus in the decision-making process as regards foreign policy and of presenting the results of this consensus internationally. The only alternative to this is, after all, the ever-increasing irrelevance of the European Union on the international stage. 